\title{
Receptor tyrosine kinases positively regulate BACE activity and Amyloid- $\beta$ production through enhancing BACE internalization
}

\author{
Lin Zou ${ }^{1,2, *}$, Zhu Wang ${ }^{1, *}$, Li Shen ${ }^{1,3}$, Guo Bin Bao ${ }^{1}$, Tian Wang ${ }^{1}$, Jiu Hong Kang ${ }^{1}$, Gang Pei ${ }^{1}$ \\ ${ }^{1}$ Laboratory of Molecular Cell Biology, Institute of Biochemistry and Cell Biology, Shanghai Institutes for Biological Sciences, Chinese \\ Academy of Sciences, Shanghai 200031, China ${ }^{2}$ Clinical Molecular Medical Center, Children's Hospital, Chongqing University of \\ Medical Sicences, Chongqing 400011, China; ${ }^{3}$ Graduate School of the Chinese Academy of Sciences, Shanghai 200031, China
}

Amyloid- $\beta$ (A $\beta$ ) peptide, the primary constituent of senile plaques in Alzheimer's disease (AD), is generated by $\beta$-secretase- and $\gamma$-secretase-mediated sequential proteolysis of the amyloid precursor protein (APP). The aspartic protease, $\beta$-site APP cleavage enzyme (BACE), has been identified as the main $\beta$-secretase in brain but the regulation of its activity is largely unclear. Here, we demonstrate that both BACE activity and subsequent A $\beta$ production are enhanced after stimulation of receptor tyrosine kinases (RTKs), such as the receptors for epidermal growth factor (EGF) and nerve growth factor (NGF), in cultured cells as well as in mouse hippocampus. Furthermore, stimulation of RTKs also induces BACE internalization into endosomes and Golgi apparatus. This enhancement of BACE activity and A $\beta$ production upon RTK activation could be specifically inhibited by Src family kinase inhibitors and by depletion of endogenous c-Src with RNAi, and could be mimicked by over-expressed c-Src. Moreover, blockage of BACE internalization by a dominant negative form of Rab5 also abolished the enhancement of BACE activity and $\mathrm{A} \beta$ production, indicating the requirement of BACE internalization for the enhanced activity. Taken together, our study presents evidence that BACE activity and $\mathrm{A} \beta$ production are under the regulation of RTKs and this is achieved via RTK-stimulated BACE internalization, and suggests that an aberration of such regulation might contribute to pathogenic $A \beta$ production.

Keywords: $\beta$-site APP cleavage enzyme, RTK, Amyloid- $\beta$, Src

Cell Research (2007) 17:389-401. doi: 10.1038/cr.2007.5; published online 27 February 2007

\footnotetext{
*These authors contributed equally to this work.

Correspondence: Gang Pei

Tel: 86-21-5492-1371; Fax: 86-21-5492-1011;

E-mail: gpei@sibs.ac.cn

Received 16 December 2006; revised 15 January 2007; accepted 16 January 2007; published online 27 February 2007

Abbreviations: AD (Alzheimer's disease); A $\beta$ (Amyloid- $\beta$ peptide); APP (amyloid precursor protein); BACE ( $\beta$-site APP cleavage enzyme); RTKs (receptor tyrosine kinases); EGF (epidermal growth factor); NGF (nerve growth factor); EEA-1 (early endosome antigen-1); LAMP-1 (lysosomalassociated membrane protein); HEK 293 (human embryonic kidney 293); PP2 (4-Amino-5-(4-chlorophenyl)-7-(t-butyl)pyrazolo[3,4-d]pyrimidine); PP3 (4-Amino-7-phenylpyrazol [3,4-d] pyrimidine); MAPK (MAP Kinase); PI3K (Phosphatidyl 3-Kinase); AEBSF (4-(2-Aminoethyl) benzenesulfonylfluoride); ELISA (Enzyme-linked Immunosorbent Assay); NS-RNAi (nonspecific RNA interference); GSK3 $\beta$ (glycogen synthase kinase $3 \beta$ )
}

\section{Introduction}

Alzheimer's disease (AD), one of the most common neurodegenerative disorders in elderly people, is characterized by the formation of senile plaques in patient brains [1]. The primary constituent of the senile plaques is amyloid- $\beta$ peptides $(A \beta)$ that are generated by sequential proteolysis of APP by $\beta$-secretase and $\gamma$-secretase [2]. Nowadays, $\beta$ secretase is considered the initial and rate-limiting enzyme during this process. $\beta$-site APP cleavage enzyme (BACE), a type I integral membrane aspartic protease, was identified as the main $\beta$-secretase [3-7]. As formation of senile plaques could not be detected in BACE-deficient mice [8, 9], BACE has attracted major attentions in AD research during recent years. For example, small molecule inhibitors of BACE have been widely investigated for their potential 
use in the treatment of $\mathrm{AD}[10]$.

Recent studies revealed that BACE is synthesized as an immature and inactive form in the endoplasmic reticulum [11], and undergoes maturation during its transport to cell surface along the secretory pathway [12-16]. The mature BACE is then internalized from cell surface to endosomes $[3,12]$, followed by sorting to the trans golgi network (TGN) for recycling or to lysosomes for degradation $[15,16]$. Interestingly, endosomal accumulation of $A \beta$ was also found in AD patients at the early disease stage [17]. These data suggested that internalization of BACE from cell surface to endosomes might be important for its activity with regard to the generation of $A \beta$. However, the direct relationship between BACE internalization and its activity as well as how BACE internalization is regulated, especially by extracellular signals, remain to be established.

Receptor tyrosine kinases (RTKs) comprise a large family of cell surface receptors, which transduce various extracellular signals to the interior of cells, mediating distinct cellular functions such as proliferation, differentiation, survival, and protein synthesis [18]. Upon activation, RTKs undergo phosporylation at specific tyrosine sites and then bind with SH2 (Src homology region) or PTB (phosphotyrosine binding) domain-containing proteins to activate downstream effectors such as c-Src, MAPK, and PKC [19]. Particularly, c-Src has been demonstrated to regulate the internalization of membrane proteins via different mechanisms [20-24], implicating a means for RTK-mediated regulation of other membrane proteins. RTK internalization is required for their normal signaling. In response to ligand stimulation, RTK internalizes and recruits a protein complex known as the 'signalsome' which contains a number of intracellular signaling molecules including c-Src [2529]. Interestingly, PDGF stimulation was shown to result in an increased cleavage of the over-expressed APP [30], suggesting a functional role of the RTK signaling pathway in the amyloidogenic process. Therefore, in this study we investigated whether $\beta$ - or $\gamma$-secretase activity could be regulated by RTKs.

\section{Materials and Methods}

\section{Antibodies and materials}

The polyclonal antibodies against BACE were purchased from Calbiochem (Cat.195100 and Cat.195111). The monoclonal antiBACE antibody (Cat. MAB5308) and antibody 6E10 against A $\beta$ were from Chemicon. Antibodies against APP-CTF, HA tag and Golgi $58 \mathrm{~K}$ protein were from Sigma. Antibodies against early endosome antigen-1 (EEA-1) and lysosomal-associated membrane protein (LAMP-1) were from BD Biosciences. Antibodies against TrkA and p75 were from Upstate, and the antibody against EGFR was from Santa Crutz Biotechnology. The following commercially available reagents were used: EGF, NGF (Sigma); PP2, PP3, Herbimycin A, Uo126, BACE inhibitor and the secretase fluorogenic substrates
(Calbiochem); AEBSF (AMESCO); Streptavidin-HRP, protein ASepharose beads (Amersham Biosciences); and complete protease inhibitor cocktail (Roche).

\section{Plasmid construction}

The RNAi plasmid for human c-Src was constructed as described [31]. A 22-mer oligonucleotide (oligo1) corresponding to nucleotide 594-615 of the c-Src coding sequence was first inserted into the pBS/U6 vector (a generous gift from Dr Yang Shi, Dept. Pathology, Harvard Medical School) with XhoI and blunted ApaI sites. The inverted motif containing a six-nucleotide spacer and five Ts (oligo2) was then subcloned into the XhoI and EcoRI sites of the intermediate plasmid to generate $\mathrm{pBS} / \mathrm{U} 6 / \mathrm{c}-\mathrm{Src}-\mathrm{RNAi}$. Oligo1 is 5'-GGC CTC AAC GTG AAG CAC TAC A-3' (forward) and 5'- AGC TTG TAG TGC TTC ACG TTG AGG CC-3' (reverse). Oligo2 is 5'-AGC TTG TAG TGC TTC ACG TTG AGG CCC TTT TTG-3' (forward) and 5'-AAT TCA AAA AGG GCC TCA ACG TGA AGC ACT ACA $-3^{\prime}$ (reverse). For the c-Src expression plasmid, mouse c-Src cDNA (Genbank, accession number NM_009271) was cloned into HindIII and EcoRI sites of pcDNA3 (Invitrogen, Carlsbad, CA).

\section{Cell culture and transfection}

Human embryonic kidney (HEK) 293 cells and rat C6 glioma cells were cultured in Modified Eagle's Medium (MEM) and Dulbecco's modified Eagle's medium (DMEM), respectively, supplemented with $10 \%$ fetal bovine serum (Life Technologies, Inc.). For generation of stable cell lines, HEK293 and C6 cells were transfected with $3 \mu \mathrm{g}$ of pcDNA3 containing Swedish APP $_{695}$ (swAPP) using LipofectAMINE (Invitrogen) according to the manufacturer's instruction. Stable expression clones were selected and maintained in G418 $(300 \mu \mathrm{g} / \mathrm{ml})$. For transient transfection, HEK293 cells were transfected by the calcium phosphate-DNA co-precipitation method as described previously [31].

\section{Intracerebroventricular (i.c.v.) injection of mouse brains}

C57/BJ mice were anaesthetized and subjected to intracerebroventricular injection of NGF $(2 \mathrm{ml}$ at $100 \mathrm{ng} / \mu \mathrm{l}$ ) or NS (normal saline) with the following coordinates: AP (anterior-posterior): $-0.6 \mathrm{~mm}, \mathrm{LR}$ (left-right): $-1.2 \mathrm{~mm}, \mathrm{DV}$ (dorsal-ventral): $-1.8 \mathrm{~mm}$ for the indicated time ( $60 \mathrm{~min}$ for $\mathrm{Ab}$ production measurement, 30 $\min$ for secretase activity assay; $\mathrm{n}=10$ for each assay). Then the hippocampi were isolated and collected for measurement of secretase activities and $\mathrm{A} \beta$ production. All animal treatments were processed in Shanghai Laboratory Animal Center in strict accordance with the National Institutes of Health Guide for the Care and Use of Laboratory Animals.

\section{Measurement of secreted and intracellular $A \beta$}

HEK293 or C6 cells stably expressing swAPP were stimulated for $1 \mathrm{~h}$ with EGF (200 ng/ml) or NGF (100 ng/ml), followed by incubation in conditioned medium for $6 \mathrm{~h}$. To measure the amount of secreted $\mathrm{A} \beta$, the conditioned medium was directly quantified for $\mathrm{A} \beta 40$ and A $\beta 42$ by sandwich ELISA kits (Biosource). To determine intracellular $A \beta$ levels, the stimulated cells were lysed in RIPA buffer (containing the protease inhibitor cocktail and AEBSF); the cell lysates were precleared with APP-CTF antibody, followed by immunoprecipitation of $A \beta$ with the antibody $6 \mathrm{E} 10$. The immunoprecipitates were separated by $15 \%$ SDS-PAGE and subjected to western blot using 6 E10. Each experiment was repeated at least three times. The optical density (OD) of each band was quantified by using Scion Image software. 
The amount of secreted $\mathrm{A} \beta$ produced in mouse hippocampus was determined by using BNT77/BA27 and BNT77/BC05 sandwich ELISA kits (Wako) according to previous reports [32].

\section{Fluorogenic substrate secretase activity assay}

This assay was performed as reported [33]. Briefly, cultured cells or mouse hippocampi were stimulated with or without RTK agonists for the indicated time periods and homogenized. The resulting aliquots (containing $15 \mu \mathrm{g}$ of proteins) were centrifuged at $13000 \times \mathrm{g}$ for 15 min. Then, the membrane pellets were recovered and incubated at $37^{\circ} \mathrm{C}$ for $30 \mathrm{~min}$ in $50 \mu \mathrm{l}$ of assay reaction buffer (for BACE, $50 \mathrm{mM}$ sodium acetate, $\mathrm{pH} 4.5$; for $\alpha$-secretase, $10 \mathrm{mM}$ Tris- $\mathrm{HCl}, \mathrm{pH} 7.5$; for $\gamma$-secretase 50 mM Tris-HCl, pH 6.8, 2 mM EDTA, 0.25\% CHAPSO) containing $10 \mu \mathrm{M}$ specific fluorogenic substrates for each secretase. After incubation, fluorescence was measured using a spectrometer at excitation/emission wavelength of 320/420 nm (for BACE), 325/393 $\mathrm{nm}$ (for $\alpha$-secretase), and 355/440 nm (for $\gamma$-secretase).

\section{Immunofluorescence microscopy}

HEK293 cells grown on coverslips were stimulated with EGF (200 $\mathrm{ng} / \mathrm{ml}$ ) for $30 \mathrm{~min}$ and fixed with $4 \%$ formaldehyde, followed by double staining with anti-BACE antibody (Calbiochem, Cat. 195100, rabbit) and antibodies against EEA-1, LAMP-1, or Golgi $58 \mathrm{~K}$ protein (mouse). Then Cy3-conjugated anti-rabbit secondary antibody and Cy5-conjugated anti-mouse secondary antibody (Jackson ImmunoResearch) were applied. Images were acquired using a laser confocal fluorescence microscope (Leica TCS SP2). The image of the Cy5-stained sample was converted to green pseudocolor. The positive colocalization rate of BACE-organelle marker was calculated from 100 randomly chosen cells in different observed fields.

\section{Fluorescence activated cell sorting (FACS) for internaliza- tion studies}

HEK293 cells were stimulated with or without EGF $(200 \mathrm{ng} / \mathrm{ml})$ and stained sequentially with anti-BACE and FITC-conjugated antirabbit secondary antibody. The background fluorescence was assessed by staining the cells with the secondary antibody alone. The stained cells were then analyzed with FACS Calibur (BD Biosciences).

\section{Cell surface biotinylation for internalization studies}

Cell surface biotinylation assay was performed as reported [12], and all procedures were carried on ice unless otherwise stated. Briefly, HEK293 cells were labeled with EZ-Link ${ }^{\mathrm{TM}}$ Sulfo-NHS-SS-Biotin (Pierce) for $30 \mathrm{~min}$ followed by washing with $100 \mathrm{mM}$ glycine to remove the free biotin. Cells were then moved to $37^{\circ} \mathrm{C}$ in absence or presence of EGF $(200 \mathrm{ng} / \mathrm{ml})$ for the indicated time periods. After washing with the striping buffer $(20 \mathrm{mM}$ Tris- $\mathrm{HCl}, \mathrm{pH}$ 8.6, $50 \mathrm{mM}$ glutathione, $150 \mathrm{mM} \mathrm{NaCl}, 1 \mathrm{mM} \mathrm{EDTA}, 0.2 \%$ bovine serum albumin) to remove all the biotin that had remained on the cell surface, cells were lysed in RIPA buffer (containing the protease inhibitor cocktail); and the lysates were immunoprecipitated with anti-BACE antibody (Calbiochem, Cat.195111). The resulting immunoprecipitates were subjected to western blot and detected by Streptavidin-HRP.

\section{Statistical analysis}

All measurements were performed in at least three independent experiments and the means \pm S.E. were calculated. Data were analyzed by Student's $t$-test for comparison of independent means, with pooled estimates of common variances. For all tests, $P<0.05$ was considered to be significant.

\section{Results}

Stimulation of RTK increases BACE activity and A $\beta$ production

Because the performance of different anti-BACE antibodies may vary for a specific application, we first examined these antibodies in our preliminary experiments. Our preliminary results showed that the anti-BACE from Calbiochem (Cat.195100) was good for immunofluorescence (Supplement 1, Figure A, left and middle panels), the anti-BACE from Calbiochem (Cat.195111) was good for immunoprecipitation (data not shown), and the anti-BACE from Chemicon (Cat. MAB5308) was suitable for western blot (Supplement 1, Figure A, right panel).

Among RTKs, receptors for EGF and NGF are widely distributed and well characterized. Here, the potential regulation of amyloidgenic secretase activities by RTKs was investigated. Activation of endogenous receptors for EGF or NGF through EGF or NGF stimulation was confirmed by Western blot analysis of ERK phosphorylation (Supplement 1, Figure B) [34], and the activities of three secretases were determined simultaneously. The results showed that only BACE activity was increased by RTK stimulation in a time-dependent manner (Figure 1A, 1C) while BACE expression was not affected (Supplement 1, Figure B); and $\alpha$ - and $\gamma$ - secretase activities were not significantly affected. This enhancement of BACE activity was completely blocked by antibodies against EGFR [35] or NGFR [36] respectively (Figure 1A, 1C). These data indicated that the observed enhancement in BACE activity was dependent on the activation of the corresponding RTK. To verify that RTK stimulation specifically enhances the activity of BACE, corresponding inhibitors for the three secretases were applied respectively: EDTA $(2.5 \mathrm{mM})$ as the inhibitor of $\alpha$-secretase, DFK167 (100 mM) as the inhibitor for $\gamma$-secretase, as well as the BACE inhibitor (125 $\mathrm{mM})$. And the results showed that only the BACE inhibitor could suppress RTK-enhanced BACE activity in HEK293 and C6 cells (Figure 1B and 1D).

Because endogenous $A \beta$ production is too little to be detected in common cell lines [37], HEK293 or C6 cells stably expressing the Swedish APP mutant 695 (denoted as swHEK293 or swC6) were used to examine whether the enhanced BACE activity led to an increase in A $\beta$ production. Following stimulation with the RTK agonist, the secreted $A \beta_{40}$ and $A \beta_{42}$ levels were enhanced to $1.967 \pm$ 0.023 and $2.040 \pm 0.140$ fold in swHEK293 cells (Figure $2 \mathrm{~A}$ ), and to $2.082 \pm 0.219$ and $2.145 \pm 0.306$ fold in swC6 cells (Figure 2B). The intracellular $\mathrm{A} \beta$ level was also significantly increased (Figure $2 \mathrm{C}-2 \mathrm{~F}$ ).

The effects of RTK activation on BACE activity as well as on $A \beta$ production were also determined in vivo. Consistent with the observed data from the cultured cells, 
A

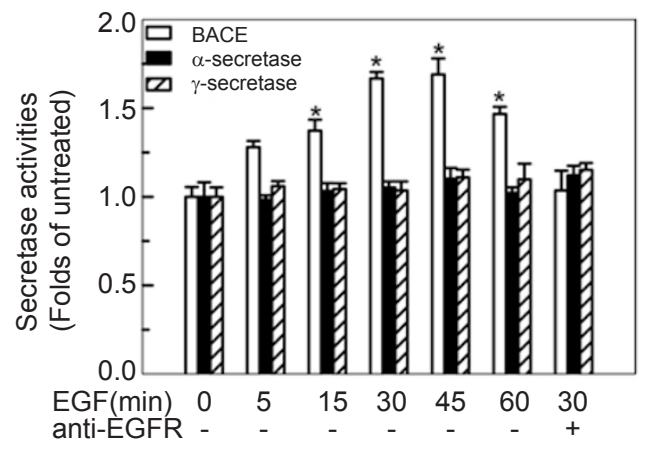

C

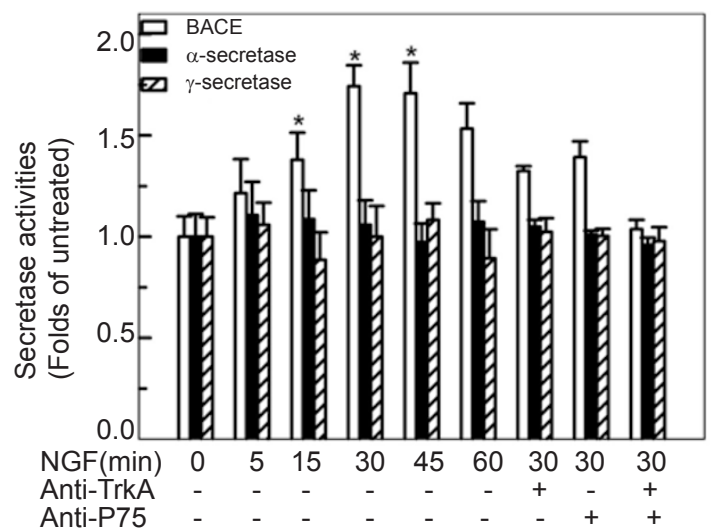

B
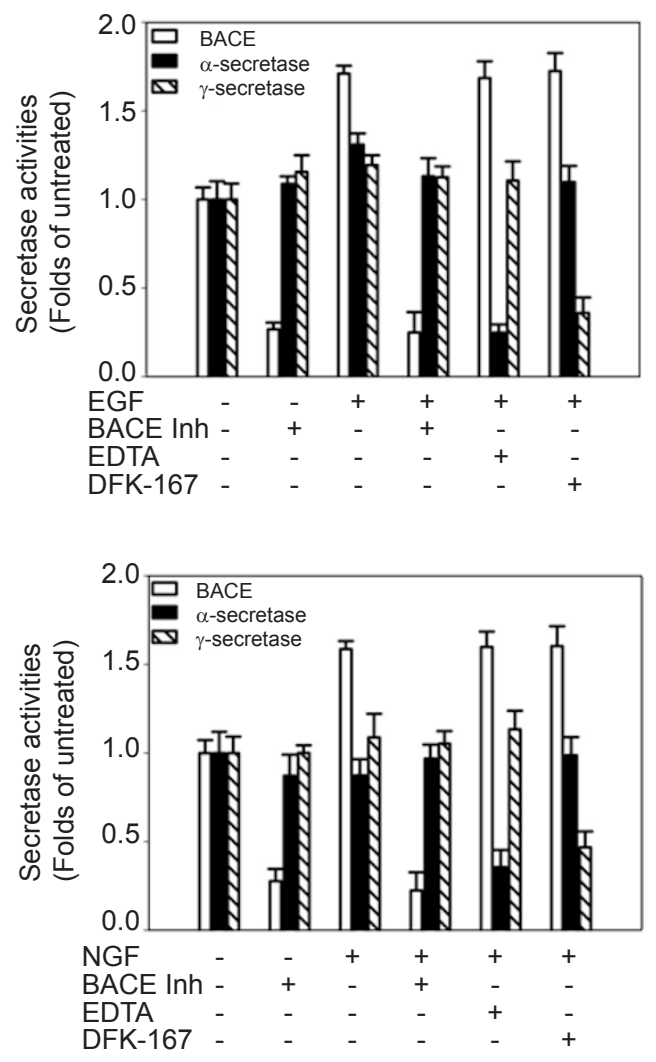

E

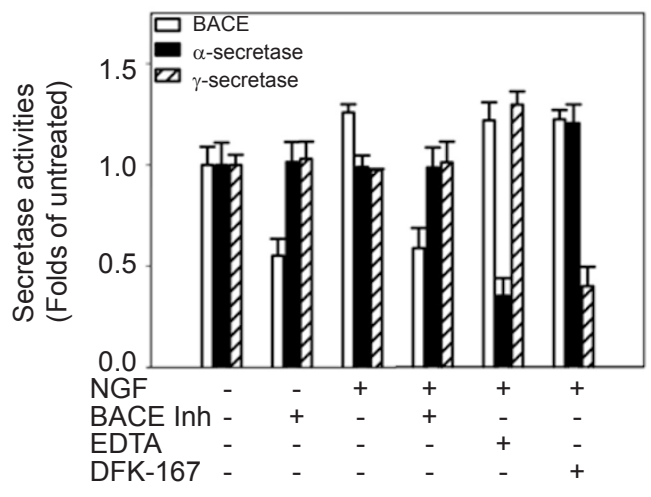

Figure 1 Activation of RTKs specifically enhances BACE activity. Secretase activities were measured by the fluorogenic substrate assay as described. (A), HEK293 cells were stimulated with EGF $(200 \mathrm{ng} / \mathrm{ml})$ for indicated time. In the last panel, cells were pretreated with anti-EGFR $(1 \mu \mathrm{g} / \mathrm{ml})$ for $15 \mathrm{~min}$. HEK293 cells (B) or rat C6 glioma cells (D) were stimulated with EGF (200 ng/ml) or NGF $(100 \mathrm{ng} / \mathrm{ml})$ for $30 \mathrm{~min}$, in presence or absence of BACE inhibitor $(125 \mu \mathrm{M})$, EDTA $(2.5 \mathrm{mM})$ or DFK-167 $(100 \mu \mathrm{M})$ respectively. (C), C6 cells were stimulated with NGF $(100 \mathrm{ng} / \mathrm{ml})$ for indicated time. In the last three panels, cells were pretreated with anti-NGFR (anti-TrkA and/or anti-P75, $1 \mu \mathrm{g} / \mathrm{ml}$ ) for $15 \mathrm{~min}$. (E) the hippocampi of C57BL/6J mice were isolated and homogenized, following the i.c.v. injection of NGF (200 ng) for $30 \mathrm{~min}, \mathrm{n}=10$; and the proteins were collected for detection of secretase activities in the presence or absence of BACE inhibitor $(125 \mu \mathrm{M})$, EDTA $(2.5 \mathrm{mM})$ or DFK-167 $(100 \mu \mathrm{M})$. Data are means \pm S.E. of three independent experiments. ${ }^{*}, P<0.05$ versus untreated cells. 
A

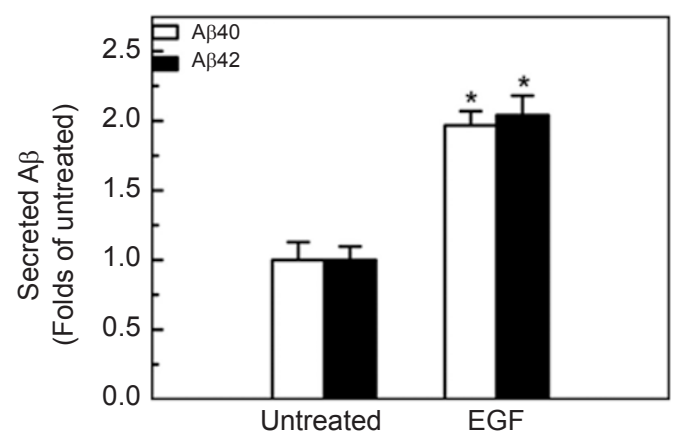

C

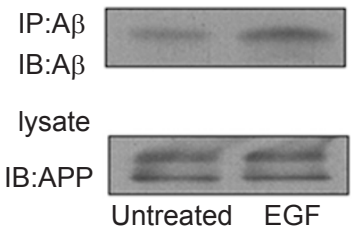

E

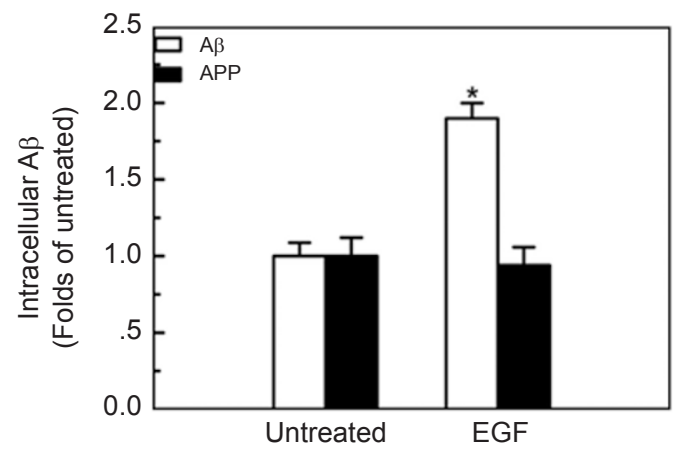

B

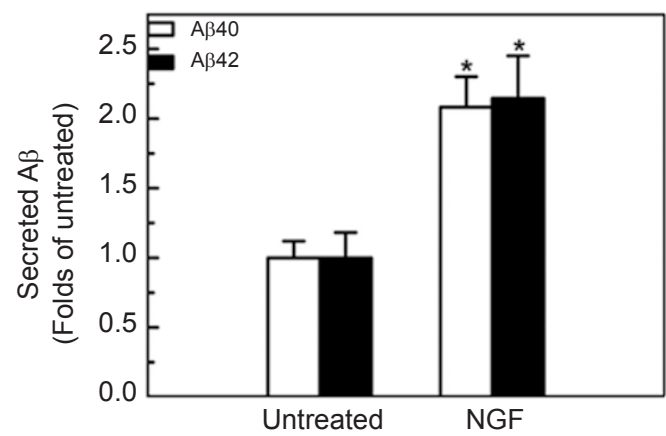

D

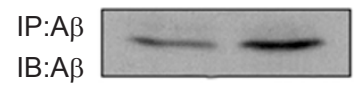

lysate

IB:APP

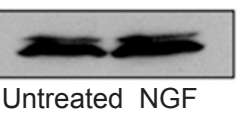

F

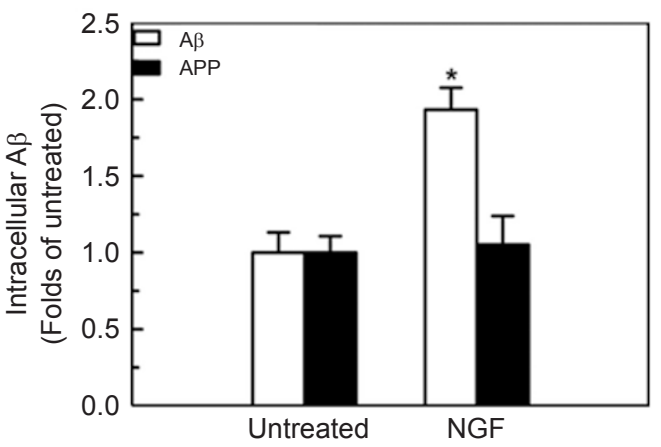

G

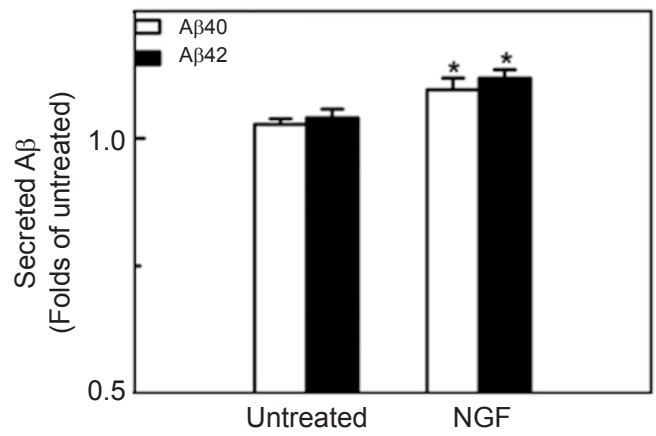

Figure 2 Activation of RTKs promotes A $\beta$ production. HEK293 and C6 cells stably expressing the Swedish APP mutant 695 (APPswe), abbreviated as swHEK293 or swC6 cells, were stimulated with EGF (200 ng/ml) or NGF (100 ng/ml) for $1 \mathrm{~h}$. The Ab secreted from swHEK293 (A) and swC6 (B) cells were measured by ELISA. The intracellular A $\beta$ in swHEK293 cells (C) or swC6 cells (D) was detected by immunoprecipitation and western blot. (E) and (F), quantitative representations of results in (C) and (D) respectively, which were from at least three independent experiments. (G), C57BL/6J mice hippocampi were isolated and homogenized after the i.c.v. injection of NGF $(200 \mathrm{ng})$ for $1 \mathrm{~h}, \mathrm{n}=10$. The supernatants were collected by ultracentrifugation at $40000 \mathrm{~g}$ for $1 \mathrm{~h}$, and $\mathrm{A} \beta$ was measured by ELISA. The values are presented as means $\pm \mathrm{S}$.E. from three independent experiments. $*, P<0.05$ versus untreated cells. 
A

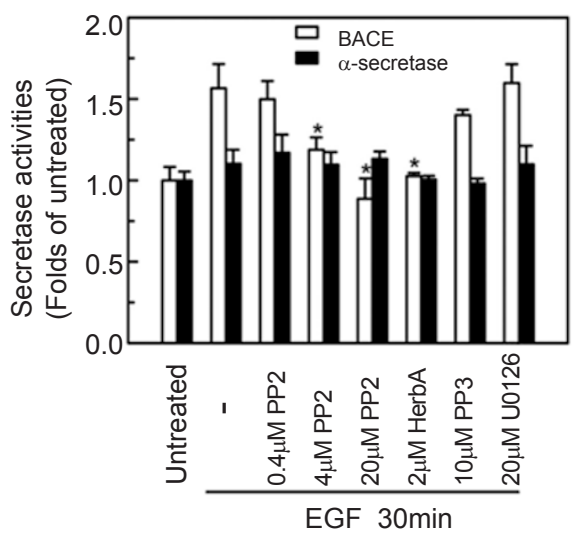

C

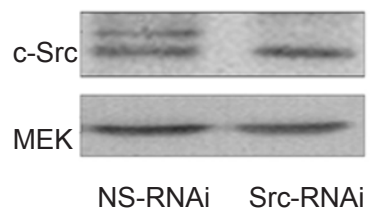

E

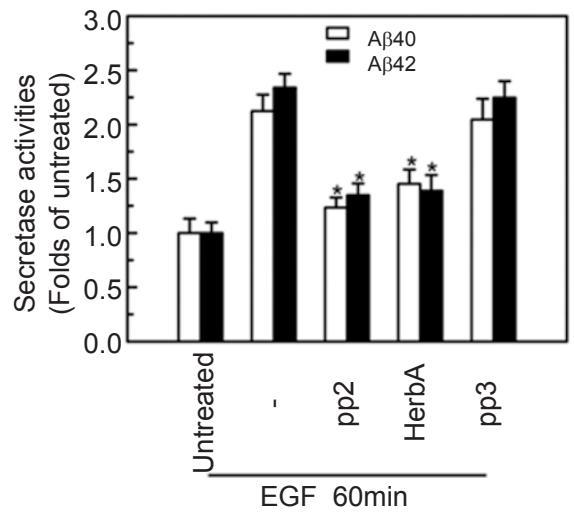

B

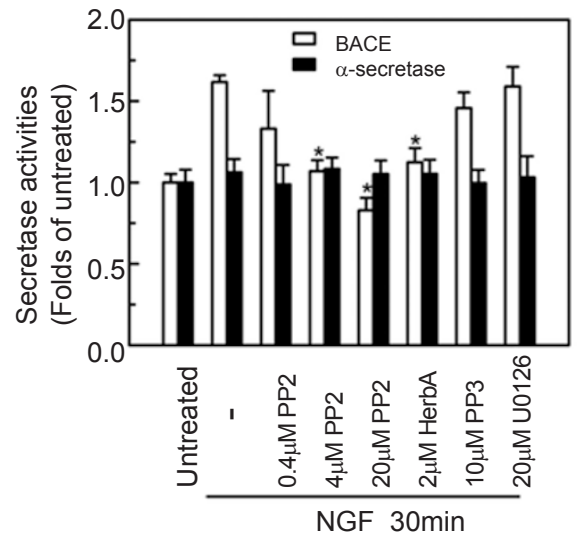

$\mathrm{D}$

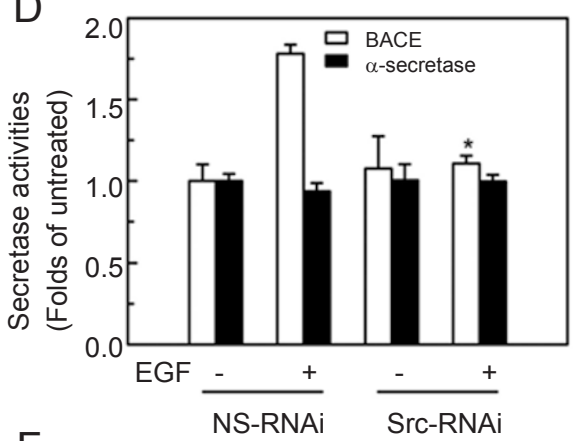

$\mathrm{F}$

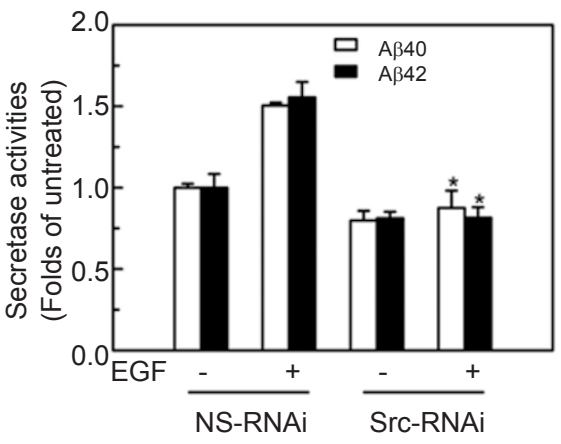

Figure $3 \mathrm{c}$-Src is required tor enhanced BACE actıvity and A $\beta$ production induced by KI K activation. (A, B, $\mathbf{V})$, the indicated secretase activities were measured by the fluorogenic substrate assay as described in Materials and Methods. HEK293 (A) or C6 glioma cells (B) were pretreated with PP2 $(0.4 \mu \mathrm{M}, 4 \mu \mathrm{M}$ and $20 \mu \mathrm{M})$, Herbimycin A $(2 \mu \mathrm{M})$, PP3 $(10 \mu \mathrm{M})$, or Uo126 (20 $\mu \mathrm{M})$, followed by stimulation with EGF $(200 \mathrm{ng} / \mathrm{ml}) \mathbf{( A )}$ or NGF $(100 \mathrm{ng} / \mathrm{ml})$ (B) for indicated time. HEK293 cells were transiently transfected with vectors for NS-RNAi or Src-RNAi (D), and $72 \mathrm{~h}$ later the cells were exposed to EGF (200 ng/ml) for $30 \mathrm{~min}$. (E, F), the secreted A $\beta$ was detected by ELISA. (E), swHEK293 cells were stimulated with EGF $(200 \mathrm{ng} / \mathrm{ml})$ for $1 \mathrm{~h}$ following the pretreatment with PP2 $(4 \mu \mathrm{M})$, PP3 $(10 \mu \mathrm{M})$ and Herbimycin A $(2 \mu \mathrm{M})$. (F), swHEK293 cells were transiently transfected with vectors for NS-RNAi or Src-RNAi, and $72 \mathrm{~h}$ later the cells were stimulated with EGF $(200 \mathrm{ng} / \mathrm{ml})$ for $1 \mathrm{~h}$. (C), endogenous expression of c-Src in cells transfected with vectors for NS-RNAi or Src-RNAi. NS: none specific, ** indicated the non-specific band. Data are means \pm S.E. of three independent experiments. * $P<0.05$ versus the absence of inhibitors (A, B, and $\mathbf{E})$ or versus NS-RNAi (D and F).

though being somewhat less potent, NGF stimulation in creased both the activity of BACE (Figure 1E) and the resulting production of $A \beta_{40}$ and $A \beta_{42}$ (Figure $2 E$ ) in mouse hippocampus. The reason underlying the less potent effect shown by the in vivo study might be due to the limited accessibility of NGF to mouse tissues. In conclusion, our 
A
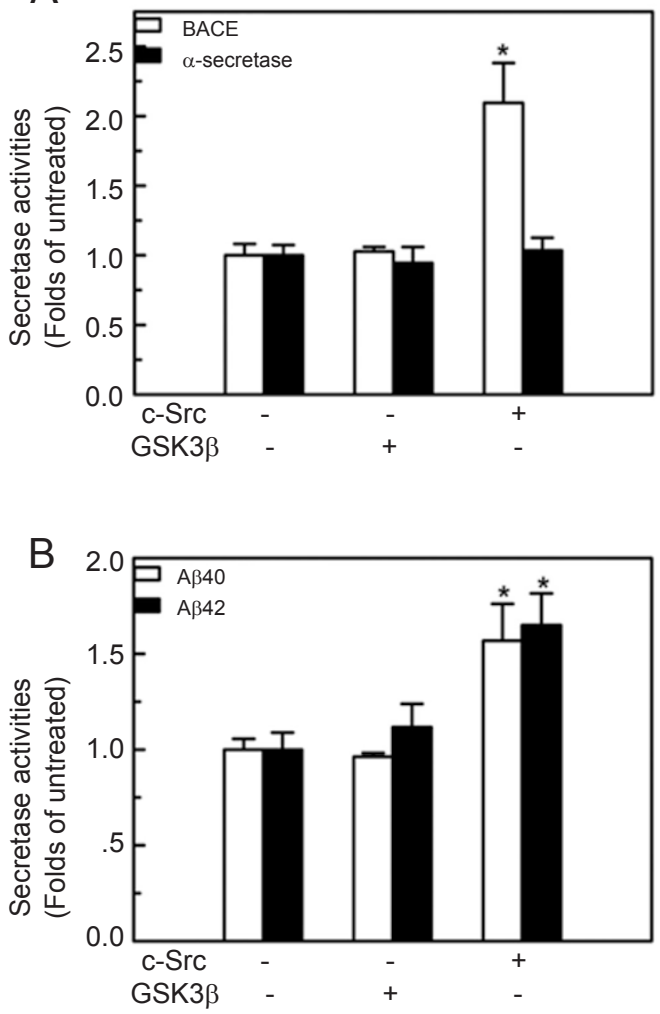

C

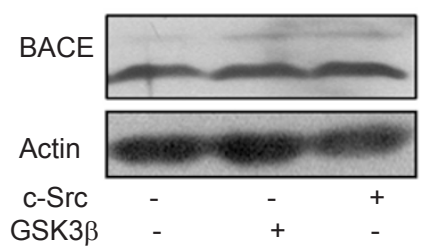

Figure $4 \mathrm{c}$-Src over-expression led to enhanced BACE activity and A $\beta$ production, mimicking that induced by RTK activation. HEK293 cells were transiently transfected with vectors expressing c-Src or GSK $3 \beta$ (as a negative control). The indicated secretase activities (A) and secreted $\mathrm{A} \beta$ (B) were measured as described. (C), Cell lysates were collected and the expression of BACE (examined by the antibody from Chemicon, Cat. MAB5308) and Actin was detected by Western blot. Data are means \pm S.E. of three independent experiments. *, $P<0.05$ versus mock transfected cells.

results show that RTK activation enhances BACE activity and $\mathrm{A} \beta$ production in vitro and in vivo.

\section{RTK-enhanced BACE activity and A $\beta$ production are mediated by $c-S r c$ \\ RTK is reported to transduce signals through various downstream effectors such as MAPK, PKC, PKA, PI3K and Src tyrosine kinases [38-40]. Therefore, we sought to}

determine which signal pathway is involved in mediating the RTK-enhanced BACE activity and $A \beta$ production. Our results showed that inhibitors of the Src family such as PP2 and Herbimycin A could block the enhancement of BACE activity induced by RTK activation; in contrast, PP3 (a nonfunctional analogue of PP2) and Uo126 (inhibitor of MEK) failed to do so (Figure 3A, 3B). The inhibitors of PKA (H-89), P38 MAPK (SB203580), PI3K (LY294002) and MAPK (PD98059) were found to have no blocking effect on RTK-mediated BACE activation (Supplement 1, Figure C). Further, specific knockdown of the endogenous c-Src, a member of the Src family, by RNAi (Figure 3C), also blocked RTK-mediated enhancement of BACE activity, while the control NS-RNAi had no effect (Figure 3D). Accordingly, inhibition of c-Src activation by its inhibitor (Figure 3E) or by RNAi (Figure 3F) could also block RTK-stimulated A $\beta$ production. Finally, over-expression of c-Src (GSK3 $\beta$ as the control) was found to mimic the effects of RTK activation on both the BACE activity and $\mathrm{A} \beta$ production (Figure $4 \mathrm{~A}$ and $4 \mathrm{~B}$ ) without affecting BACE expression (Figure $4 \mathrm{C}$ ). Taken together, these results show that $\mathrm{c}-\mathrm{Src}$ mediates the enhanced BACE activity and $\mathrm{A} \beta$ production induced by RTK activation.

\section{RTK activation enhances BACE internalization in a c-Src dependent manner}

Because BACE is known to be internalized, and sorted to endosomes and the Golgi apparatus to exert its cleavage activity [3, 12], we thus studied whether RTK activation affects the intracellular distribution of BACE. As shown in Figure 5, BACE was localized in endosomes (EEA-1 as the marker) and Golgi apparatus (Golgi $58 \mathrm{~K}$ protein as the marker), with little in lysosomes (LAMP-1 as the marker), consistent with other reports [3,15]. Following EGF stimulation, the localization of BACE in endosomes (Figure 5A) was significantly increased, and its localization in the Golgi apparatus was also slightly increased (Figure $5 \mathrm{~B})$, suggesting that RTK activation could enhance BACE internalization. This conclusion was also supported by the results shown in Figure 6. In response to EGF, the amount of BACE on cell surface decreased significantly as detected by either FACS analysis (Figure 6A and 6B) or by the cell surface biotinylation assay (Figure 6C-6E). Furthermore, BACE internalization was mediated by c-Src, as evidenced by the observation that it could be blocked by PP2 (Figure 5A, A7-A9, Figure 5B, B7-B9) and mimicked by c-Src over-expression (Figure $7 \mathrm{~B}$ and $7 \mathrm{G}$ ).

\section{$B A C E$ internalization enhances its activity and $A \beta$ pro- duction}

Since c-Src could enhance both the internalization and the activity of BACE, the relationships between BACE 
A
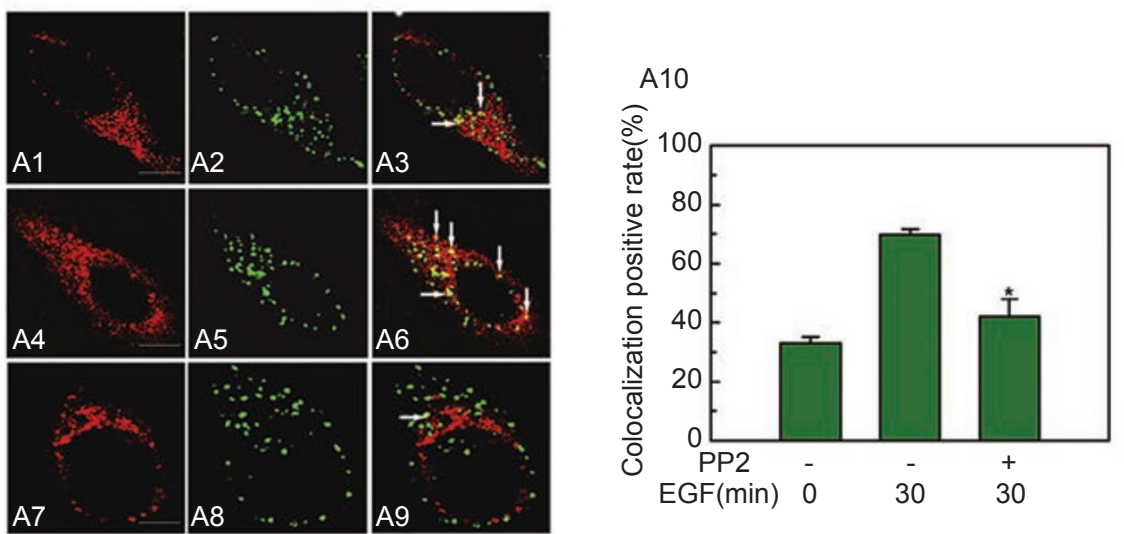

B
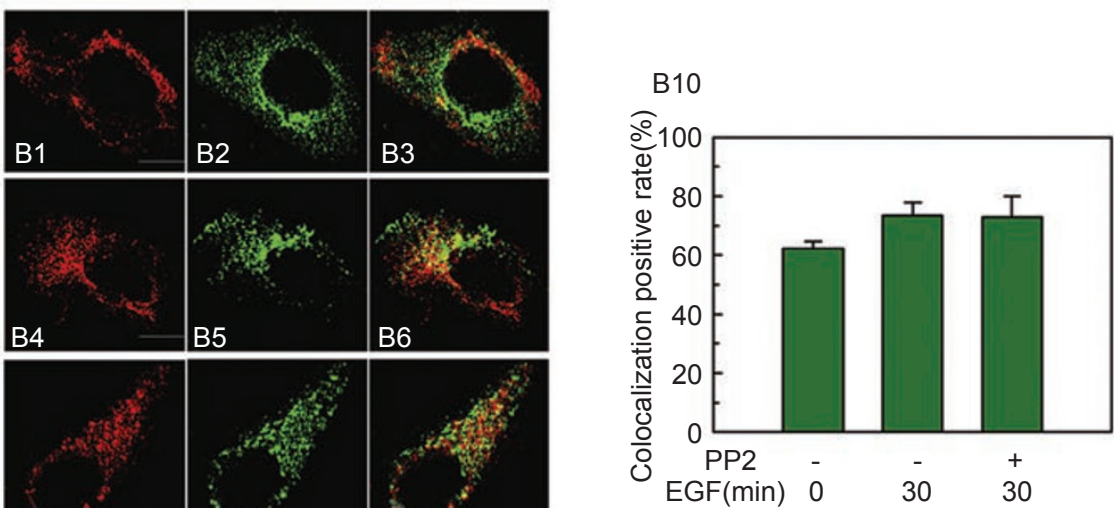

C
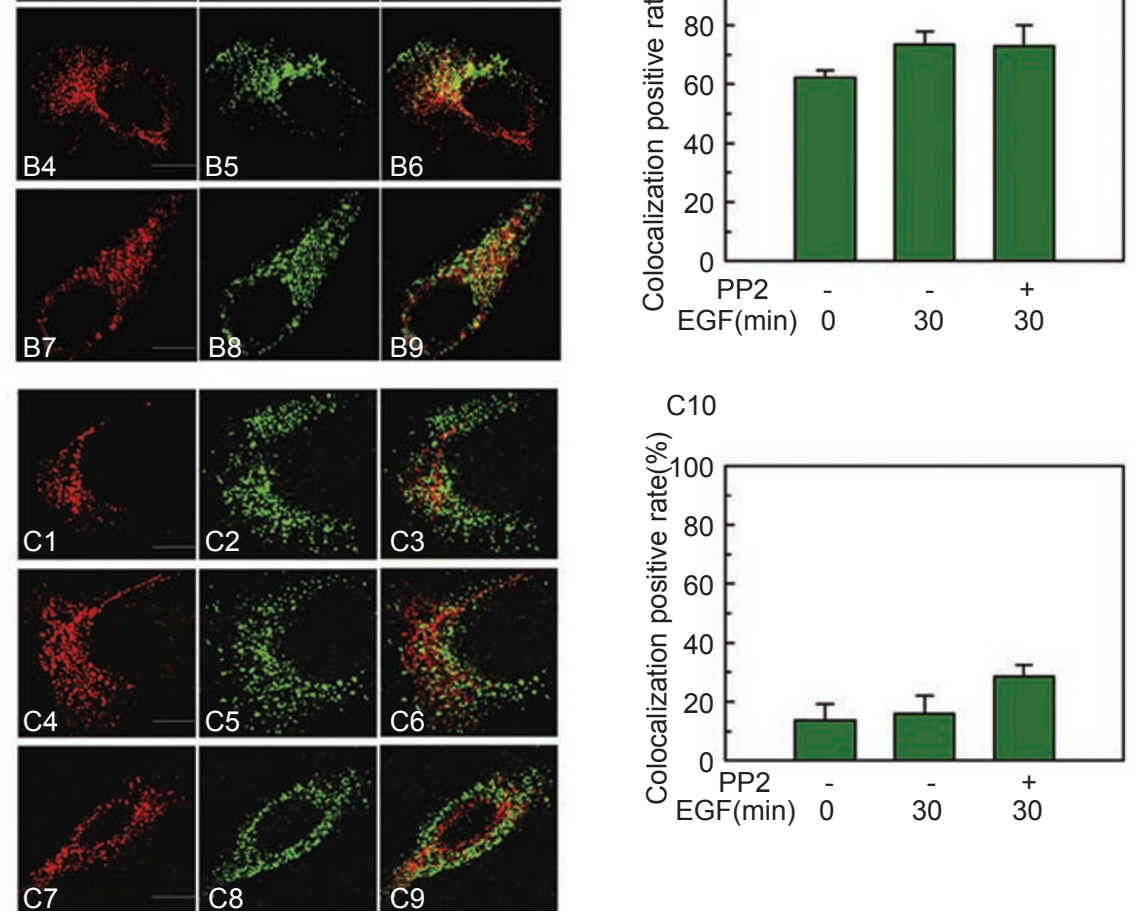

Figure 5 Activation of RTKs increases BACE localization in the endosome and Golgi apparatus. HEK293 cells were stimulated with EGF $(200 \mathrm{ng} / \mathrm{ml})$ for $30 \mathrm{~min}$ in the presence or absence of PP2 $(4 \mu \mathrm{M})$ pretreatment $(5 \mathrm{~min})$, fixed and double-stained with antibodies against BACE (Calbiochem, Cat. 195100) and molecular markers (green) for endosome (EEA-1 as the marker), Golgi apparatus (Golgi 58K protein as the marker), or lysosome (LAMP-1 as the marker). (A1-A9), BACE and EEA-1; (A1-A3), untreated, scale bar=14 $\mu \mathrm{m}$; (A4-A6), 30 min EGF stimulation, scale bar=14 $\mu \mathrm{m}$; (A7-A9), 30 min EGF stimulation following PP2 pretreatment, scale bar $=21 \mu \mathrm{m}$. (A10), quantitative results of BACE/EEA-1 co-localization in 100 cells. (B1-B9), BACE and Golgi 58K protein; (B1-B3), untreated, scale bar=21 $\mu \mathrm{m}$; (B4-B6), 30 min EGF stimulation, scale bar=21 $\mu \mathrm{m}$; (B7-B9), 30 min EGF stimulation following PP2 pretreatment, scale bar=21 $\mathrm{m}$. (B10), quantitative results of BACE/Golgi co-localization in 100 cells. (C1-C9), BACE and LAMP-1; (C1-C3), untreated, scale bar=21 $\mu \mathrm{m}$; (C4-C6), 30 min EGF stimulation, scale bar=21 $\mu \mathrm{m}$; (C7-C9), 30 min EGF stimulation following PP2 pretreatment, scale bar $=12 \mu \mathrm{m}$. (C10), quantitative results of BACE/lysosome co-localization in 100 cells. All the experiments were performed at least three times. *, $P<0.05$ versus EGF stimulated cells. 
A

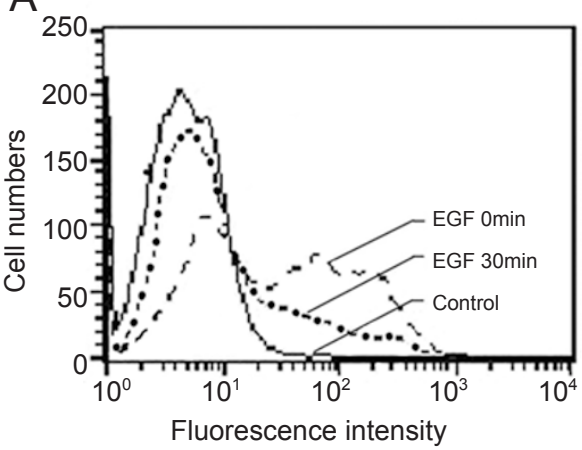

C

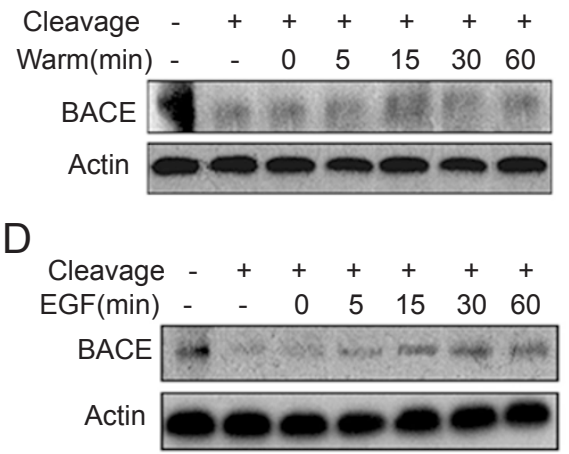

$B$

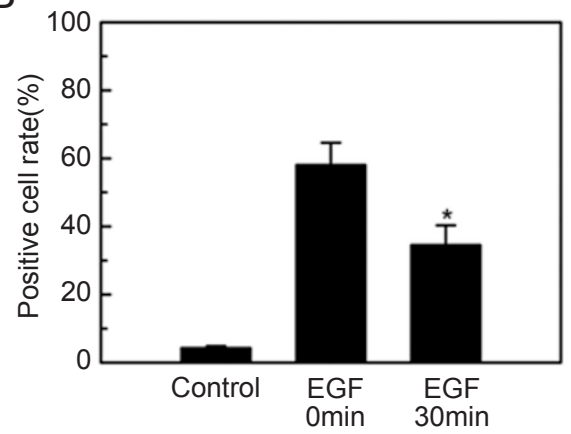

$E$

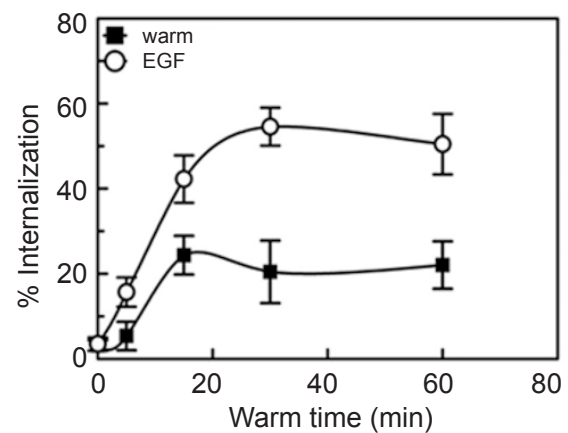

Figure 6 Activation of RTK decreases BACE localization on cell surface. (A, B), HEK293 cells were stimulated with (EGF $30 \mathrm{~min}$ ) or without (untreated, 0 min) EGF, stained sequentially with anti-BACE (Calbiochem, Cat.195100) and FITC-conjugated secondary antibody, followed by detection with flow cytometry. Cells stained with the secondary antibody alone were used to assess the fluorescence background (control). The quantitative results from three independent experiments are shown in (B). *, $P<0.05$ versus the untreated cells. (C, D, E), HEK293 cells were labeled with $0.5 \mathrm{mg} / \mathrm{ml} \mathrm{EZ-Link}{ }^{\mathrm{TM}}$ Sulfo-NHS-SS-Biotin (Pierce) at $4{ }^{\circ} \mathrm{C}$ for $30 \mathrm{~min}$. The reaction was stopped by treating with $100 \mathrm{mM}$ glycine for $15 \mathrm{~min}$, and cells were then incubated at $37^{\circ} \mathrm{C}$ for the indicated time in MEM medium with $(\mathbf{D}$, EGF) or without $(\mathbf{C}$, warm $)$ EGF $(200 \mathrm{ng} / \mathrm{ml})$. The internalized BACE was detected as described in "Materials and Methods". (E), the statistical plot was generated from three independent experiments performed in (C) and (D). Each dot represents the relative optical density of internalized BACE at different time points compared with the first lane (total BACE expression on the cell surface at time 0 ).

internalization and BACE activity as well as $\mathrm{A} \beta$ production were further investigated. For this purpose, we co-expressed c-Src with GFP-Rab5S34N, a dominant negative form of Rab5 capable of disrupting protein internalization to endosomes [41], to block BACE internalization. As expected, c-Src-enhanced BACE internalization was completely blocked by GFP-Rab5S34N, but not by GFPRab7T22N (the dominant negative mutant for lysosome formation) [42] (Figure 7C-7E and 7H-7J). Accordingly, the presence of GFP-Rab5S34N, but not GFP-Rab7T22N, also blocked the enhanced BACE activity and $\mathrm{A} \beta$ production normally induced by c-Src over-expression (Figure 7K and $7 \mathrm{~L}$ ). In conclusion, BACE internalization was required for enhanced $B A C E$ activity and subsequent $A \beta$ production upon c-Src activation.

\section{Discussion}

As the only $\beta$-secretase known to generate $A \beta$ in brain, $\mathrm{BACE}$ has proven to be a key molecule in the formation of senile plaques $[8,9,43,44]$. Up to now, studies of BACE have concentrated on its structure $[4,45]$, trafficking [11, $16,46-50]$, and specific inhibition [10], but how its activity is regulated remains largely unclear. In this study, we demonstrated that BACE activity both in vitro and in vivo could be efficiently regulated by RTKs, and the regulation of BACE activity led to alterations of subsequent $A \beta$ production. RTKs, a large family of cell surface receptors mediating various extracellular signals, have been reported to regulate APP expression and secretion $[51,52]$ and to be aberrantly activated at the early disease stages in $A D$ 

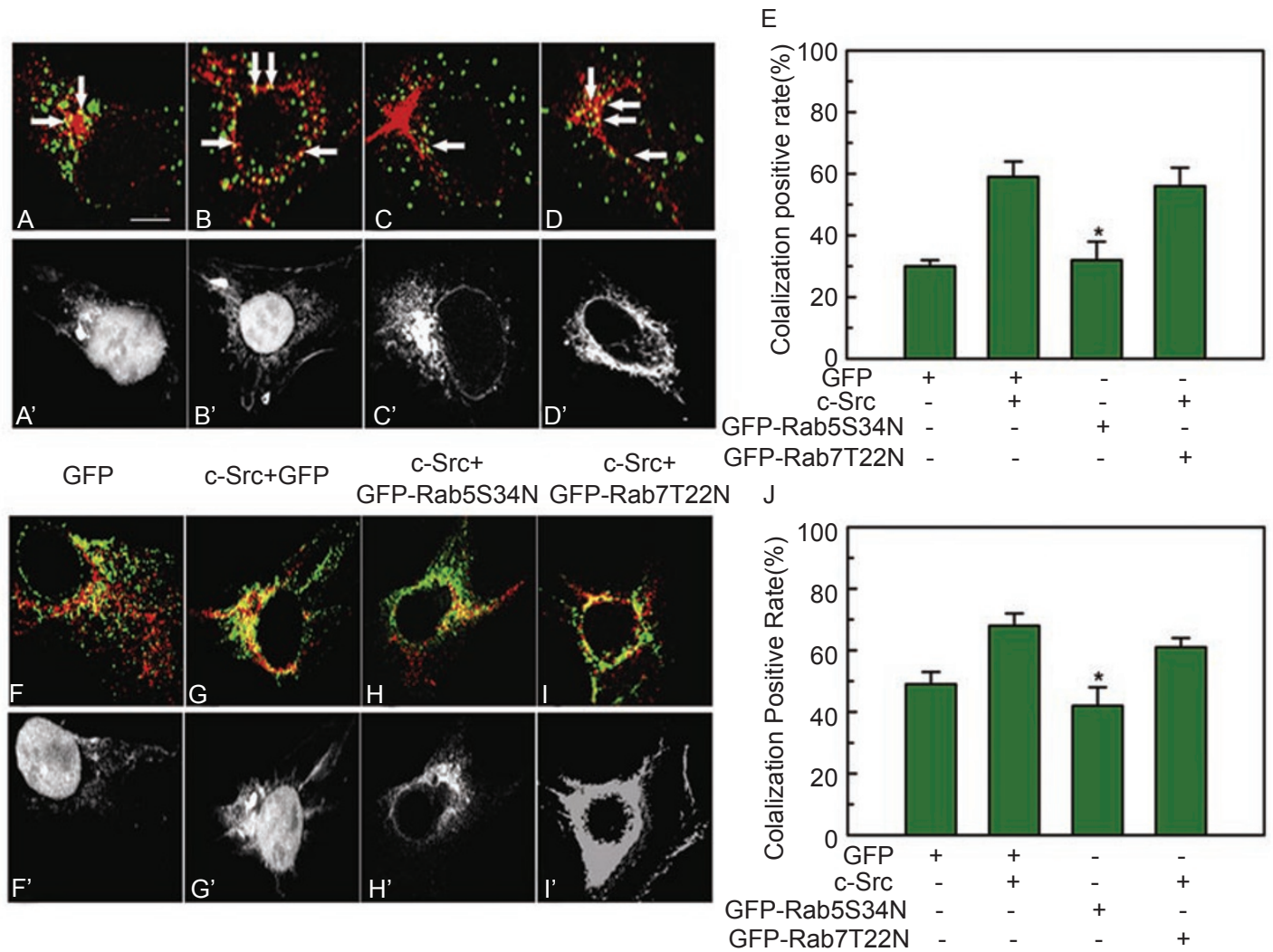

L
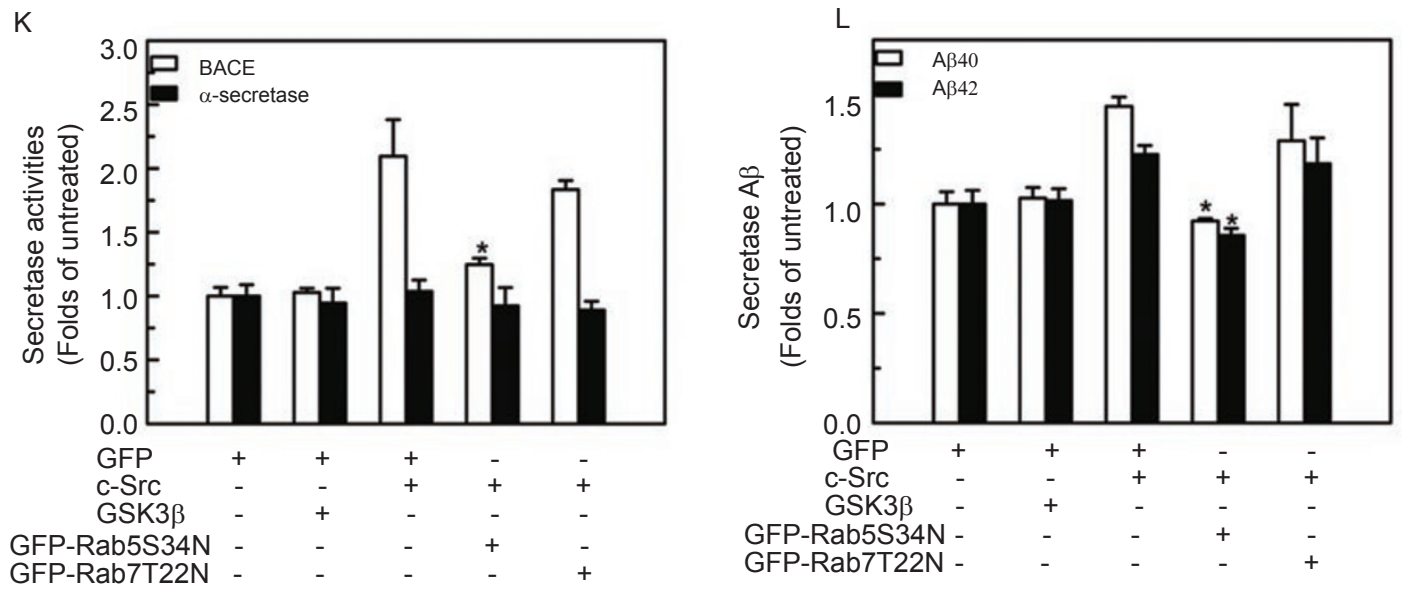

Figure 7 BACE internalization enhances BACE activity and A $\beta$ production. HEK293 cells transfected with the indicated constructs were fixed and double-stained with antibodies against BACE (Calbiochem, Cat.195100) and molecular markers (green) for endosome (EEA-1) or Golgi apparatus (Golgi 58K protein). The co-localization of BACE/EEA-1 (A-D) or BACE/Golgi 58K protein (F-I) was detected. (A'-D') and (F'-I') show the success of different transfections, scale bar $=30 \mu \mathrm{m}$. The positive co-localization rate of BACE/EEA-1 (E) and BACE/Golgi 58K protein $(\mathrm{J})$ in 100 cells is shown; and the experiments were repeated independently three times. (K), HEK293 cells were transfected as above, with GSK3 $\beta$ as a negative control. Forty-eight hours later, membranes were subjected to the analysis of BACE and $\beta$-secretase activities. (L). swHEK293 cells were co-transfected as in (K), 48 hours later, the supernatants were collected for analysis of secreted A $\beta$. Data are means \pm S.E. of at least three independent experiments. ${ }^{*}, P<0.05$ versus cells cotransfected with c-Src and GFP in (E, J, K) and (L).

patients [53-55]. In light of the critical roles of BACE activity in $A \beta$ production, our results suggest that RTKs may contribute to the development of AD.
Upon stimulation, RTKs function by activating downstream signaling molecules such as c-Src, MAPK, and PKC [38-40] or by inducing the internalization of other 
membrane proteins such as E-cadherin [56]. This study demonstrated that stimulation of RTKs induced BACE internalization to enhance BACE activity and subsequent $\mathrm{A} \beta$ production, which were independent of MAPK and PKC activation (data not shown). RTK-induced BACE internalization results in accumulation of BACE in endosomes where the acidic environment could provide optimum $\mathrm{pH}$ BACE activity. In addition, it has been reported that APP and BACE are co-internalized into endosomes, leading to enhanced APP cleavage there [57-60]. Thus, the abnormally enlarged endosomes observed in the early stages of AD [17] might be due to abnormal internalization of BACE and $\mathrm{APP}$, leading to enhanced $\mathrm{A} \beta$ production. It is tempting to speculate that regulation of BACE and APP internalization by RTK activation is critical for $A \beta$ production, and that an aberration of such regulation might contribute to the senile plaque formation.

c-Src is an integral component of the signal transduction apparatus employed by RTKs [61] and plays pivotal roles in the internalization of various membrane proteins such as $\beta 2 \mathrm{AR}, \mathrm{ROMK}-1$, AT1R, and EGFR. Consistent with these reports, we demonstrated that RTK-induced $\mathrm{BACE}$ internalization and subsequent $\mathrm{A} \beta$ production also depended on the activity of c-Src. In addition, overexpression of c-Src itself could mimic the effects of RTK activation, indicating that c-Src is not only necessary but also sufficient for BACE internalization. It is known that c-Src mediates internalization of membrane proteins by phosphorylating the internalized protein or components of the internalization machinery [20-22, 24]. Our results suggest that in this case c-Src may phosphorylate components of the internalization machinery because no tyrosine residue was found in the cytosolic tail of BACE [16, 21, 23, 24, 62, 63]. Although the precise mechanism of enhanced BACE internalization mediated by c-Src still remains unclear, the results from this study indicate that c-Src may serve as a potential therapeutic target for AD.

$\mathrm{AD}$ pathogenesis was recently found to be modulated by environmental factors such as education, mental/leisure activity, depression, and stress, some of which affect signaling events in the brain [64-66]. Remarkably, we found in our recent study that $\beta 2$-adrenoceptor signaling, which mediates the stress response in animals, regulates $\gamma$-secretase activity and senile plaque formation in vivo [67]. Our present study shows that extracellular signals, at least those mediated by RTKs, could increase $A \beta$ production by enhancing BACE activity. The physiological significance of this RTK activation-enhanced BACE activity is supported by the results of the mouse hippocampus study, which showed that this enhancement of BACE activity led to increased $A \beta$ production in the major brain region affected by $\mathrm{A} \beta$ accumulation. Hence, our study opens a new window for understanding the regulation of $\mathrm{BACE}$ activity and $\mathrm{A} \beta$ production in $\mathrm{AD}$ in response to environmental factors.

\section{Acknowledgments}

We thank Dr Z Chen for construction of pcDNA3-c-Src and pBS-U6-Src RNAi plasmids, S Xiang, W Zhang and Angie L Bookout for manuscript revisions, and S Xin and $\mathrm{Y} \mathrm{Wu}$ for technical assistance. This research was supported by grants from the Ministry of Science and Technology (2003CB515405, 2005CB522406), the National Natural Science Foundation of China (30021003, 30400230, 30625014), the Chinese Academy of Sciences (KSCX1SW, KSCX2-SW), the Ministry of Education, Shanghai Municipal Commission for Science and Technology (06ZR14098), China Post Doctoral Science Foundation, and Shanghai Postdoctoral Science Foundation.

\section{References}

1 Selkoe DJ. Alzheimer's disease: genes, proteins, and therapy. Physiol Rev 2001; 81:741-766.

2 Esch FS, Keim PS, Beattie EC, et al. Cleavage of amyloid beta peptide during constitutive processing of its precursor. Science 1990: 248:1122-1124.

3 Vassar R, Bennett BD, Babu-Khan S, et al.\{Beta\}-Secretase Cleavage of Alzheimer's Amyloid Precursor Protein by the Transmembrane Aspartic Protease BACE. Science 1999: 286:735-741.

4 Lin X, Koelsch G, Wu S, Downs D, Dashti A, Tang J. Human aspartic protease memapsin 2 cleaves the beta-secretase site of beta-amyloid precursor protein. Proc Natl Acad Sci USA 2000; 97:1456-1460.

5 Sinha S, Anderson JP, Barbour R, et al. Purification and cloning of amyloid precursor protein beta-secretase from human brain. Nature 1999; 402:537-540.

6 Yan R, Bienkowski MJ, Shuck ME, et al. Membrane-anchored aspartyl protease with Alzheimer's disease beta-secretase activity. Nature 1999; 402:533-537.

7 Hussain I, Powell D, Howlett DR, et al. Identification of a novel aspartic protease (Asp 2) as beta-secretase. Mol Cell Neurosci 1999; 14:419-427.

8 Luo Y, Bolon B, Kahn S, et al. Mice deficient in BACE1, the Alzheimer's beta-secretase, have normal phenotype and abolished beta-amyloid generation. Nat Neurosci 2001; 4:231-232.

9 Roberds SL, Anderson J, Basi G, et al. BACE knockout mice are healthy despite lacking the primary beta-secretase activity in brain: implications for Alzheimer's disease therapeutics. Hum Mol Genet 2001; 10:1317-1324.

10 John V, Beck JP, Bienkowski MJ, Sinha S, Heinrikson RL. Human beta-secretase (BACE) and BACE inhibitors. J Med Chem 2003; 46:4625-4630.

11 Capell A, Steiner H, Willem M, et al. Maturation and pro-peptide cleavage of beta-secretase. J Biol Chem 2000; 275:3084930854.

12 Huse JT, Pijak DS, Leslie GJ, Lee VM, Doms RW. Maturation and endosomal targeting of beta-site amyloid precursor protein- 
cleaving enzyme. The Alzheimer's disease beta-secretase. J Biol Chem 2000; 275:33729-33737.

13 Bennett BD, Denis P, Haniu M, et al. A furin-like convertase mediates propeptide cleavage of BACE, the Alzheimer's beta -secretase. J Biol Chem 2000; 275:37712-37717.

14 Creemers JW, Ines Dominguez D, Plets E, et al. Processing of beta-secretase by furin and other members of the proprotein convertase family. J Biol Chem 2001; 276:4211-4217.

15 Koh YH, von Arnim CA, Hyman BT, Tanzi RE, Tesco G. BACE is degraded via the lysosomal pathway. J Biol Chem 2005; 280:32499-32504.

16 Walter J, Fluhrer R, Hartung B, et al. Phosphorylation regulates intracellular trafficking of beta-secretase. J Biol Chem 2001; 276:14634-14641.

17 Nixon RA. Endosome function and dysfunction in Alzheimer's disease and other neurodegenerative diseases. Neurobiol Aging 2005; 26:373-382.

18 Hoyer S. Glucose metabolism and insulin receptor signal transduction in Alzheimer disease. Eur J Pharmacol 2004;490:115125.

19 Alberts B, Johnson A, Lewis J, Raff M, Roberts K, Walter P. Molecular Biology of the Cell 2002. 4th Ed., Garland Science, New York

20 Fessart D, Simaan M, Laporte SA. c-Src regulates clathrin adapter protein 2 interaction with beta-arrestin and the angiotensin II type 1 receptor during clathrin- mediated internalization. Mol Endocrinol 2005; 19:491-503.

21 Huang J, Sun Y, Huang XY. Distinct roles for Src tyrosine kinase in beta2-adrenergic receptor signaling to MAPK and in receptor internalization. J Biol Chem 2004; 279:21637-21642.

22 Sterling H, Lin DH, Gu RM, Dong K, Hebert SC, Wang WH. Inhibition of protein-tyrosine phosphatase stimulates the dynamin-dependent endocytosis of ROMK1. J Biol Chem 2002; 277:317-4323.

23 Ahn S, Kim J, Lucaveche CL, et al. Src-dependent tyrosine phosphorylation regulates dynamin self-assembly and ligandinduced endocytosis of the epidermal growth factor receptor. J Biol Chem 2002; 277:26642-26651.

24 Wilde A, Beattie EC, Lem L, et al. EGF receptor signaling stimulates SRC kinase phosphorylation of clathrin, influencing clathrin redistribution and EGF uptake. Cell 1999; 96:677-687.

25 Howe CL, Valletta JS, Rusnak AS, Mobley WC. NGF signaling from clathrin-coated vesicles: evidence that signaling endosomes serve as a platform for the Ras-MAPK pathway. Neuron 2001; 32:801-814.

26 Barbieri MA, Roberts RL, Gumusboga A, et al. Epidermal growth factor and membrane trafficking. EGF receptor activation of endocytosis requires Rab5a. J Cell Biol 2000; 151:539-550.

27 Vieira AV, Lamaze C, Schmid SL. Control of EGF receptor signaling by clathrin-mediated endocytosis. Science 1996; 274:2086-2089.

28 Chen X, Wang Z. Regulation of epidermal growth factor receptor endocytosis by wortmannin through activation of Rab5 rather than inhibition of phosphatidylinositol 3-kinase. EMBO Rep 2001; 2:842-849.

29 Wiley HS, Burke PM. Regulation of receptor tyrosine kinase signaling by endocytic trafficking. Traffic 2001; 2:12-18.

30 Gianni D, Zambrano N, Bimonte M, et al. Platelet-derived growth factor induces the beta-gamma-secretase-mediated cleavage of
Alzheimer's amyloid precursor protein through a Src-Rac-dependent pathway. J Biol Chem 2003; 278:9290-9297.

31 Sun Y, Cheng Z, Ma L, Pei G. Beta-arrestin2 is critically involved in CXCR4-mediated chemotaxis, and this is mediated by its enhancement of p38 MAPK activation. J Biol Chem 2002; 277:49212-49219.

32 Ramsden M, Nyborg AC, Murphy MP, et al. Androgens modulate beta-amyloid levels in male rat brain. J Neurochem 2003; 87:1052-1055.

33 Andrau D, Dumanchin-Njock C, Ayral E, et al. BACE1- and BACE2-expressing human cells: characterization of betaamyloid precursor protein-derived catabolites, design of a novel fluorimetric assay, and identification of new in vitro inhibitors. J Biol Chem 2003; 278:25859-25866.

34 Minden A, Lin A, McMahon M, et al. Differential activation of ERK and JNK mitogen-activated protein kinases by Raf-1 and MEKK. Science 1994; 266:1719-1723.

35 Modjtahedi H, Affleck K, Stubberfield C, Dean C. EGFR blockade by tyrosine kinase inhibitor or monoclonal antibody inhibits growth, directs terminal differentiation and induces apoptosis in the human squamous cell carcinoma HN5. Int J Oncol 1998; 13:335-342.

36 Miklossy J, Khalili K, Gern L, et al. Borrelia burgdorferi persists in the brain in chronic lyme neuroborreliosis and may be associated with Alzheimer disease. J Alzheimers Dis 2004; 6:639-649.

37 Li Y, Wang H, Wang S, Quon D, Liu YW, Cordell B. Positive and negative regulation of APP amyloidogenesis by sumoylation. Proc Natl Acad Sci USA 2003; 100:259-264.

38 Amos S, Martin PM, Polar GA, Parsons SJ, Hussaini IM. Phorbol 12-myristate 13-acetate induces epidermal growth factor receptor transactivation via protein kinase Cdelta/c-Src pathways in glioblastoma cells. J Biol Chem 2005; 280:7729-7738.

39 Shah BH, Farshori MP, Catt KJ. Neuropeptide-induced transactivation of a neuronal epidermal growth factor receptor is mediated by metalloprotease-dependent formation of heparin-binding epidermal growth factor. J Biol Chem 2004; 279:414-420.

40 Shah BH, Soh JW, Catt KJ. Dependence of gonadotropin-releasing hormone-induced neuronal MAPK signaling on epidermal growth factor receptor transactivation. J Biol Chem 2003; 278:2866-2875.

$41 \mathrm{Hu}$ Y, Chuang JZ, Xu K, McGraw TG, Sung CH. SARA, a FYVE domain protein, affects Rab5-mediated endocytosis. J Cell Sci 2002; 115:4755-4763.

42 Bucci C, Thomsen P, Nicoziani P, McCarthy J, van Deurs B. Rab7: a key to lysosome biogenesis. Mol Biol Cell 2000; 11:467480.

43 Mohajeri MH, Saini KD, Nitsch RM. Transgenic BACE expression in mouse neurons accelerates amyloid plaque pathology. J Neural Transm 2004; 111:413-425.

44 Cai H, WangY, McCarthy D, et al. BACE1 is the major betasecretase for generation of Abeta peptides by neurons. Nat Neurosci 2001; 4:233-234.

45 Hong L, Koelsch G. Lin X, et al. Structure of the protease domain of memapsin 2 (beta-secretase) complexed with inhibitor. Science 2000; 290:150-153.

46 Kitazume S, Tachida Y, Oka R, Shirotani K, Saido TC, Hashimoto Y. Alzheimer's beta-secretase, beta-site amyloid precursor protein-cleaving enzyme, is responsible for cleavage secretion 
of a Golgi-resident sialyltransferase. Proc Natl Acad Sci USA 2001; 98:13554-13559.

47 von Arnim CA, Tangredi MM, Peltan ID, et al. Demonstration of BACE (beta-secretase) phosphorylation and its interaction with GGA1 in cells by fluorescence-lifetime imaging microscopy. J Cell Sci 2004; 117:5437-5445.

48 Shiba T, Kametaka S, Kawasaki M, et al. Insights into the phosphoregulation of beta-secretase sorting signal by the VHS domain of GGA1. Traffic 2004; 5:437-448.

49 Westmeyer GG, Willem M, Lichtenthaler SF, et al. Dimerization of beta-site beta-amyloid precursor protein-cleaving enzyme. J Biol Chem 2004; 279:53205-53212.

50 He X, Li F, Chang WP, Tang J. GGA proteins mediate the recycling pathway of memapsin 2 (BACE). J Biol Chem 2005; 280:11696-11703.

51 Villa A, Latasa MJ, Pascual A. Nerve growth factor modulates the expression and secretion of beta-amyloid precursor protein through different mechanisms in PC12 cells. J Neurochem 2001; 77:1077-1084.

52 Rossner S, Ueberham U, Schliebs R, Perez-Polo JR, Bigl V. p75 and TrkA receptor signaling independently regulate amyloid precursor protein mRNA expression, isoform composition, and protein secretion in PC12 cells. J Neurochem 1998; 71:757766.

53 Hock CH, Heese K, Olivieri G, et al. Alterations in neurotrophins and neurotrophin receptors in Alzheimer's disease. J Neural Transm Suppl 2000; 59:171-174.

54 Yankner BA, Caceres A, Duffy LK. Nerve growth factor potentiates the neurotoxicity of beta amyloid. Proc Natl Acad Sci USA 1990; 87:9020-9023.

55 Fahnestock M, Michalski B, Xu B, Coughlin MD. The precursor pro-nerve growth factor is the predominant form of nerve growth factor in brain and is increased in Alzheimer's disease. Mol Cell Neurosci 2001; 18:210-220.

$56 \mathrm{Lu} \mathrm{Z}$, Ghosh S, Wang Z, Hunter T. Downregulation of caveolin-1 function by EGF leads to the loss of E-cadherin, increased transcriptional activity of beta-catenin, and enhanced tumor cell invasion. Cancer Cell 2003; 4:499-515.

57 Huang XP, Chang WP, Koelsch G, Turner RT, 3rd Lupu F, Tang
J. Internalization of exogenously added memapsin 2 (betasecretase) ectodomain by cells is mediated by amyloid precursor protein. J Biol Chem 2004; 279:37886-37894.

58 Kinoshita A, Fukumoto H, Shah T, Whelan CM, Irizarry MC, Hyman BT. Demonstration by FRET of BACE interaction with the amyloid precursor protein at the cell surface and in early endosomes. J Cell Sci 2003; 116:3339-3346.

59 Schmechel A, Strauss M, Schlicksupp A, et al. Human BACE forms dimers and colocalizes with APP. J Biol Chem 2004; 279:39710-39717.

60 Grbovic OM, Mathews PM, Jiang Y, et al. Rab5-stimulated up-regulation of the endocytic pathway increases intracellular beta-cleaved amyloid precursor protein carboxyl-terminal fragment levels and Abeta production. J Biol Chem 2003; 278:3126131268.

61 Shupnik MA. Crosstalk between steroid receptors and the cSrc-receptor tyrosine kinase pathways: implications for cell proliferation. Oncogene 2004; 23:7979-7989.

62 Pastorino L, Ikin AF, Nairn AC, Pursnani A, Buxbaum JD. The carboxyl-terminus of BACE contains a sorting signal that regulates BACE trafficking but not the formation of total A(beta). Mol Cell Neurosci 2002; 19:175-185.

63 Miller WE, Maudsley S, Ahn S, Khan KD, Luttrell LM, Lefkowitz RJ. beta-arrestin1 interacts with the catalytic domain of the tyrosine kinase c-SRC. Role of beta-arrestin1-dependent targeting of c-SRC in receptor endocytosis. J Biol Chem 2000; 275: 11312-11319.

64 Mayeux R. Epidemiology of neurodegeneration. Annu Rev Neurosci 2003; 26:81-104.

65 Lazarov O, Robinson J, Tang YP, et al. Environmental enrichment reduces Abeta levels and amyloid deposition in transgenic mice. Cell 2005; 120:701-713.

66 Jankowsky JL, Melnikova T, Fadale DJ, et al. Environmental enrichment mitigates cognitive deficits in a mouse model of Alzheimer's disease. J Neurosci 2005; 25:5217-5224.

$67 \mathrm{Ni}$ Y, Zhao X, Bao G, et al. Activation of beta(2)-adrenergic receptor stimulates gamma-secretase activity and accelerates amyloid plaque formation. Nat Med 2007; 12:1390-1396.

(Supplementary information is linked to the online version of the paper on the Cell Research website.) 